Original Research Article

\title{
Rosuvastatin plus fenofibrate in diabetic dyslipidemia: a hospital record based study
}

\author{
K. Madhana Gopal ${ }^{1}$, M. Meganathan ${ }^{1 *}$, S. Vithiavathi ${ }^{2}$, S. Prabhu Shankar ${ }^{2}$, \\ K. Balamurugan ${ }^{3}$, Deepa Kameswari P. ${ }^{1}$
}

\begin{abstract}
${ }^{1}$ Department of Pharmacology, ${ }^{2}$ Department of General Medicine, Aarupadai Veedu Medical College and Hospital, Puducherry, India

${ }^{3}$ Department of Pharmacy, FEAT, Annamalai University, Chennai, Tamil Nadu, India
\end{abstract}

Received: 25 October 2018 Accepted: 30 October 2018

*Correspondence to: Dr. M. Meganathan, Email: dr_mega1969@ yahoo.co.in

Copyright: (C) the author(s), publisher and licensee Medip Academy. This is an openaccess article distributed under the terms of the Creative Commons Attribution NonCommercial License, which permits unrestricted noncommercial use, distribution, and reproduction in any medium, provided the original work is properly cited.

\begin{abstract}
Background: Cardiovascular diseases (CVD) are the leading cause of death throughout world population each and every year. Focus on dyslipidemia management is urgently required in India to halt the rising tide of CVD. The purpose of diabetic dyslipidemia study is a record based one, to find out the effect of Rosuvastatin plus Fenofibrate, in adult Type 2 diabetes with dyslipidemia, with high TGL/HDL ratio in Lipid profiles, in a tertiary care hospital in the Union territory of Puducherry.

Methods: There were 101 patients hospital records were analysed in which male were 45 and females were 56 . The various biochemical parameters like serum Total Cholesterol, HDL, LDL, TGL, Non-HDL, TCL/HDL Ratio and TGL/HDL ratio reports were collected before and after 12-weeks of Rosuvastatin $10 \mathrm{mg}$ with Fenofibrate $145 \mathrm{mg}$ combination, for the treatment period once daily for their lipid-lowering therapy.

Results: The combination therapies of Rosuvastatin plus Fenofibrate were safe and feasible to achieve more TG goal and proved that has predominately decreased the elevated lipid profiles from the medical resources of our record based study. The use of combination medications of rosuvastatin (10mg) plus Fenofibrate $(145 \mathrm{mg})$ is often needed to effectively treat the lipid triad, by the potency of rosuvastatin to lower LDL-C and Fenofibrates effectiveness in lowering TG in treating mixed diabetic dyslipidemia.

Conclusions: After Rosuvastatin (10mg) plus Fenofibrate (145mg), the lipid profile data proved that the importance of TGL/HDL ratio apart from the TCL/HDL ratio, for good lipid control in diabetic dyslipidemic patients.
\end{abstract}

Keywords: Cardiovascular disease, Diabetic dyslipidemia, Fenofibrates, Rosuvastatin

\section{INTRODUCTION}

Cardiovascular disease (CVD) is the leading cause of morbidity and mortality worldwide. ${ }^{1}$ According to the Centers for Disease Control, the CVD are the leading cause of death in U.S, more than 600,000 ( 1 in 4) die of heart disease each year. CVD is the most common, killing $>370,000$ people annually. ${ }^{2}$ Recent studies proved that high cholesterol is present in 25 to $30 \%$ of urban and 15 to
$20 \%$ rural populations and the prevalence is lower than high income countries. ${ }^{3}$

Increase in cardiovascular risk and hypercholesterolemia are associated in modern lifestyles. In India, recently there is an alarming increase in the prevalence of CVD risk over the past two decades at a younger age than other populations, with lower HDL cholesterol; increase triglyceride levels. ${ }^{4}$ Focus on dyslipidemia management is urgently required in India to halt the rising tide of CHD. 
Importance of TGL/HDL ratio apart from the TCL/HDL ratio, for good lipid control in diabetic dyslipidemic patients may prevent CVD. Hence, our study focuses on the hospital records of diabetic dyslipidemia patients on Rosuvastatin plus Fenofibrate therapy. The patient's biochemical parameters like serum Total Cholesterol, HDL, LDL, TGL, Non-HDL, TCL/HDL Ratio and TGL/HDL ratio were collected before and after 12-weeks of therapy. The purpose of the findings shall emphasize the importance of TGL/HDL ratio apart from the TCL/HDL ratio, for good lipid control in dyslipidemic patients. Clinic based management of dyslipidemias in India can be improved with better physician education, as well as patient empowerment for better cholesterol control. ${ }^{5}$

\section{METHODS}

This study was carried out in Aarupadai Veedu Medical College and Hospital, Puducherry, based on hospital records for the past one year (September 2017- to August 2018). Patients with diabetic dyslipidemia who were on Rosuvastatin plus Fenofibrate were taken up for the study. The study protocol was approved by Institutional research committee of Aarupadai Veedu Medical College and Hospital, Puducherry (IRC No: AV/IRC/2018/079 dated 03.10.2018). The subjects were men and women from $25-$ 70 years of age, with Type 2 diabetes mellitus with dyslipidemia. From the selected patients the hospital records for various biochemical parameters like serum Total Cholesterol, HDL, LDL, TGL, Non-HDL, TCL/HDL Ratio and TGL/HDL ratio were collected in a systematic and computerized way. The above biochemical investigations were noted before and after 12-weeks of Rosuvastatin $10 \mathrm{mg}$ with Fenofibrate $145 \mathrm{mg}$ combination, for the treatment period once daily for their lipid-lowering therapy.

The inclusion and the exclusion criteria were as follows, the male and female diabetic patients having Body Mass Index (BMI) $<36 \mathrm{~kg} / \mathrm{m}^{2}$, glycemic control ( HbA1C <7\%), were included in the study. The patients with continuous or periodic use of corticosteroids, drug induced nephro toxicity, secondary causes of albuminuria such as obstructive renal disease, renal stone disease and acute urinary tract infection, known proteinuria / ketonuria patients, patient with severe T1DM complication, preexisting macro-vascular condition and pregnant females or who had given birth within the preceding 6 weeks, malignancy, severe infection, respiratory disease and liver disorder were excluded from the study. ${ }^{6,7}$ Our study has a total number of 101 patients of which male were 45 and females were 56. Data from the Medical Record Department of the Institute were summarized as the number of observations, and the mean, standard deviation by analysis of variance (ANOVA).

\section{RESULTS}

The Table 1 to 8 results indicate the observational reports of before Rosuvastatin and Fenofibrates therapy; Table 9 shows the results of fixed dose combination of Rosuvastatin and Fenofibrates before and after therapy in adult diabetes with dyslipidemia patients. In this study pattern 101 patients data were collected, male 45 and females 56, the age group $>25$ was nil in both male and female. In between 30-40 age group males and females were 10 and 9 respectively, in 41-50 group 11 and 19, between 51-60 age group males 12 and females 15 above 61 range males 15 and females 10 (Table 1).

Table 1: Age group.

\begin{tabular}{|lll|}
\hline $\begin{array}{l}\text { Age group } \\
\text { Male }\end{array}$ & $\begin{array}{l}\text { Number of } \\
\text { cases in males }\end{array}$ & $\begin{array}{l}\text { Number of } \\
\text { cases in females }\end{array}$ \\
\hline$>25$ & NIL & NIL \\
\hline $30-40$ & 10 & 9 \\
\hline $41-50$ & 11 & 19 \\
\hline $51-60$ & 12 & 15 \\
\hline$>61$ & 15 & 10 \\
\hline
\end{tabular}

The total cholesterol levels are categorized in to three groups (Table 2), between 150-200 (mg/dl), 200-250 $(\mathrm{mg} / \mathrm{dl})$ and $>250(\mathrm{mg} / \mathrm{dl})$. In between 150-200 (mg/dl) group the numbers of patients of males and females were 33 and 45 in between 200-250 (mg/dl) group 12 and 11 and $>250$ nil.

Table 2: Serum total cholesterol level.

\begin{tabular}{|lll|}
\hline $\begin{array}{l}\text { Before treatment of Rosuvastatin and Fenofibrates } \\
\text { Serum } \\
\text { cholesterol } \\
\text { level (mg/dl) }\end{array}$ & $\begin{array}{l}\text { Number of } \\
\text { cases in males } \\
\text { ( } \mathbf{m g} / \mathbf{d l})\end{array}$ & $\begin{array}{l}\text { Number of } \\
\text { cases in females } \\
\text { (mg/dl) }\end{array}$ \\
\hline $150-200$ & 33 & 45 \\
\hline $200-250$ & 12 & 11 \\
\hline$>250$ & Nil & Nil \\
\hline
\end{tabular}

According the Serum HDL level the patients were divided in to four groups (Table 3$)$. In between $31-35(\mathrm{mg} / \mathrm{dl})$ the number of cases was nil, 36-40 (mg/dl) group the male and female were 16 and 50; between 41-45 (mg/dl) serum HDL level groups the male and female 29 and 6.

Table 3: Serum HDL level.

\begin{tabular}{|c|c|c|}
\hline \multicolumn{3}{|c|}{ Before treatment of Rosuvastatin and Fenofibrates } \\
\hline $\begin{array}{l}\text { Serum HDL } \\
\text { level (mg/dl) }\end{array}$ & $\begin{array}{l}\text { Number of } \\
\text { cases in males }\end{array}$ & $\begin{array}{l}\text { Number of cases } \\
\text { in females }\end{array}$ \\
\hline $31-35$ & Nil & Nil \\
\hline $36-40$ & 16 & 50 \\
\hline $41-45$ & 29 & 06 \\
\hline$>45$ & Nil & Nil \\
\hline
\end{tabular}

Based on the Serum LDL level (mg/dl) the patients were divided in to four groups (Table 4) in which $<100(\mathrm{mg} / \mathrm{dl})$ male and female one in each. Between 100-130 (mg/dl) group male 38 and female 43; in 131-160 (mg/dl) male 7 and female 11 and $>160(\mathrm{mg} / \mathrm{dl})$ nil in each case. 
Table 4: Serum LDL level.

\begin{tabular}{|lll|}
\hline \multicolumn{2}{|l|}{ Before treatment of Rosuvastatin and Fenofibrates } \\
\hline $\begin{array}{l}\text { Serum } \mathbf{L D L} \\
\text { level }(\mathbf{m g} / \mathbf{d l})\end{array}$ & $\begin{array}{l}\text { Number of } \\
\text { cases in males }\end{array}$ & $\begin{array}{l}\text { Number of } \\
\text { cases in females }\end{array}$ \\
\hline$<100$ & 1 & 1 \\
\hline $100-130$ & 38 & 43 \\
\hline $131-160$ & 7 & 11 \\
\hline$>160$ & Nil & Nil \\
\hline
\end{tabular}

Serum TGL level of the patients were divided in to three groups (Table 5), <150 (mg/dl) the male and female were one in each; in 151-500 (mg/dl) males 44 and female 55, and $>500(\mathrm{mg} / \mathrm{dl})$ nil.

Table 5: Serum TGL level.

\begin{tabular}{|lll|}
\hline \multicolumn{2}{|l|}{ Before treatment of Rosuvastatin and Fenofibrates } \\
$\begin{array}{l}\text { Serum TGL } \\
\text { level } \mathbf{( m g / d l})\end{array}$ & $\begin{array}{l}\text { Number of } \\
\text { cases in males }\end{array}$ & $\begin{array}{l}\text { Number of } \\
\text { cases in females }\end{array}$ \\
\hline$<150$ & 1 & 1 \\
\hline $151-500$ & 44 & 55 \\
\hline$>500$ & Nil & Nil \\
\hline
\end{tabular}

The Serum Non HDL level of the patients were divided in to three groups in first group $<100(\mathrm{mg} / \mathrm{dl})$ the male and female were nil; in second group 101-130 (mg/dl) only one female and no male and third group $>130$ (mg/dl) category males 45 and females 55 (Table 6).

Table 6: Serum Non HDL level.

\begin{tabular}{|lll|}
\begin{tabular}{l} 
Before treatment of Rosuvastatin and Fenofibrates \\
\hline $\begin{array}{l}\text { Serum Non } \\
\text { HDL level } \\
(\mathbf{m g} / \mathbf{d l})\end{array}$
\end{tabular} & $\begin{array}{l}\text { Number of } \\
\text { cases in males }\end{array}$ & $\begin{array}{l}\text { Number of cases } \\
\text { in females }\end{array}$ \\
\hline$<100$ & Nil & Nil \\
\hline $101-130$ & Nil & 1 \\
\hline$>130$ & 45 & 55 \\
\hline
\end{tabular}

Based on the Serum TCL / HDL <3.0 group both male and female were nil, in-between 3.0-4.5 group males 2 and females 1; in $>4.5$ group males 43 and females 55 respectively (Table 7).

Table 7: Serum TCL / HDL ratio.

\begin{tabular}{|lll|}
\hline \multicolumn{2}{|l|}{ Before treatment of Rosuvastatin and Fenofibrates } \\
\hline $\begin{array}{l}\text { Serum TCL / } \\
\text { HDL ratio }\end{array}$ & $\begin{array}{l}\text { Number of cases } \\
\text { in males }\end{array}$ & $\begin{array}{l}\text { Number of } \\
\text { cases in females }\end{array}$ \\
\hline$<3.0$ & Nil & Nil \\
\hline $3.0-4.5$ & 2 & 1 \\
\hline$>4.5$ & 43 & 55 \\
\hline
\end{tabular}

The Serum TGL/HDL ratio (Table 8) shows that $<3.0$ group both male and females nil, and $>3.0$ group 45 males and 56 females were found.
Table 8: Serum TGL/HDL ratio.

\begin{tabular}{|lll|}
\hline \multicolumn{3}{|l|}{ Before treatment of Rosuvastatin and Fenofibrates } \\
\hline $\begin{array}{l}\text { Serum TGL/ } \\
\text { HDL ratio }\end{array}$ & $\begin{array}{l}\text { Number of } \\
\text { cases in males }\end{array}$ & $\begin{array}{l}\text { Number of } \\
\text { cases in females }\end{array}$ \\
\hline$<3.0$ & Nil & Nil \\
\hline$>3.0$ & 45 & 56 \\
\hline
\end{tabular}

Before and after treatment of treatment of Rosuvastatin and Fenofibrates diabetes patients (Table 9). The Serum Total Cholesterol (mg/dl) was 196.03 \pm 8.72 and 169.82 \pm 10.23 ; the HDL (mg/dl) was $40.13 \pm 1.673$ and 44.96 \pm 1.782 ; LDL (mg/dl) was 120.37 \pm 6.55 and $83.34 \pm 6.73$, TGL (mg/dl) $179.68 \pm 13.58$ and 158.94 \pm 15.204 , non-HDL (mg/dl) was $156.47 \pm 8.07$ and $122.48 \pm 8.734$, the TCL/HDL ratio was $4.884 \pm 0.210$ and $4.249 \pm 0.270$ and TGL/HDL ratio 4.477 \pm 0.282 and $3.977 \pm 0.294$ respectively.

Table 9: Results of the observational study fixed dose combination of Rosuvastatin and Fenofibrates before and after therapy- in adult diabetes with dyslipidemia.

\begin{tabular}{|lll|}
\hline $\begin{array}{l}\text { Observations and } \\
\text { biochemical } \\
\text { parameters }\end{array}$ & $\begin{array}{l}\text { Before } \\
\text { treatment of } \\
\text { Rosuvastatin } \\
\text { and } \\
\text { Fenofibrates }\end{array}$ & $\begin{array}{l}\text { After } \\
\text { treatment of } \\
\text { Rosuvastatin } \\
\text { and } \\
\text { Fenofibrates }\end{array}$ \\
\hline $\begin{array}{l}\text { Serum total } \\
\text { cholesterol (mg/dl) }\end{array}$ & $196.03 \pm 8.72$ & $169.82 \pm 10.23$ \\
\hline HDL (mg/dl) & $40.13 \pm 1.673$ & $44.96 \pm 1.782$ \\
\hline LDL $(\mathrm{mg} / \mathrm{dl})$ & $120.37 \pm 6.55$ & $83.34 \pm 6.73$ \\
\hline TGL $(\mathrm{mg} / \mathrm{dl})$ & $179.68 \pm 13.58$ & $158.94 \pm 15.204$ \\
\hline Non-HDL $(\mathrm{mg} / \mathrm{dl})$ & $156.47 \pm 8.07$ & $122.48 \pm 8.734$ \\
\hline TCL/HDL Ratio & $4.884 \pm 0.210$ & $4.249 \pm 0.270$ \\
\hline TGL/HDL Ratio & $4.477 \pm 0.282$ & $3.977 \pm 0.294$ \\
\hline
\end{tabular}

\section{DISCUSSION}

The standard lipid profile guidelines to treat patients with metabolic syndrome like diabetes the normal value includes serum Total Cholesterol 40-200 (mg/dl), HDL 45-65 (mg/dl), LDL (DM) 50-70 and (NDM) 70-100 (mg/dl), TGL 0-150 (mg/dl), Non-HDL (DM) <100 and $(\mathrm{NDM})<130(\mathrm{mg} / \mathrm{dl})$, TCL/HDL ratio $<3.0-4.5$ and TGL/HDL ratio $<3 .^{8}$

In this study pattern 101 patients data were analysed based on age group (Table 1), serum Total Cholesterol (Table 2), Serum HDL level (Table 3), Serum LDL level (Table 4), Serum TGL level (Table 5), Serum Non HDL level (Table 6), Serum TCL / HDL ratio (Table 7) and Serum TGL/HDL ratio (Table 8 ).

According to the American Heart Association, young women have a much lower risk of cardiovascular disease due to the protective role of the hormone estrogens. Men 45 years or older are at a higher risk, and also younger men need attention too, further the American Heart Association 
journal Circulation indicated that insulin resistance play a major role in the increased risk of Cardiovascular disorders for younger men. In this case females were more in number than males indicate that mixed diabetic dyslipidemia and also less sample size. The gender-related changes in insulin resistance in adolescents and found that insulin resistance was more frequent in males than females, despite leaner body types in the males.

In diabetes the insulin resistance is associated with a decrease in HDL and an increase in triglycerides. ${ }^{9,10} \mathrm{~A}$ high link between insulin resistances and atherosclerosis in Type 2 diabetes causes blood vessel disease. The treatment of Rosuvastatin and Fenofibrates has elevated the HDL cholesterol and decreased LDL cholesterol. The cluster of lipid abnormalities or the diabetic dyslipidemia associated primarily with Type 2 diabetes may be the cause of a high concentration of TG and LDL and low HDL cholesterol. The lipid abnormalities may be seen due to the unbalanced diet, high content saturated fats in the foods, excessive weight, lack of exercise, genes and also certain medications and medical conditions involving thyroid, might cause the patients at risk for premature atherosclerosis and coronary heart disease. It is quite common that atherosclerosis and blood vessel disease may develop even before diabetes is diagnosed. ${ }^{11,12}$

The treatment of Rosuvastatin and Fenofibrates has altered the Serum Total Cholesterol, LDL, and TGL and subsequent gradual increase in HDL (Table 9). Lowering LDL has become a primary goal in cardiovascular prevention and commonly estimated from quantitative measurements of total and HDL-cholesterol and plasma triglycerides (TG) using the empirical relationship of Friedewald et al. And also, LDL has been associated with the development of plaque deposits on artery walls, which narrow the passage and restrict blood flow. ${ }^{13,14}$

After the Rosuvastatin (10mg) plus Fenofibrate (145mg) treatment the TCL/HDL Ratio and TGL/HDL Ratio were decreased indicating a good lipid profile control (Table 9). The total cholesterol to HDL cholesterol ratio is a number that is helpful in predicting atherosclerosis, the process of fatty build-up in the walls of the arteries. The number is obtained by dividing total cholesterol by HDL cholesterol. A high ratio indicates a higher risk of heart attack while a low ratio indicates a lower risk. Non-HDL cholesterol is a strong marker of risk, an abnormal ratio of triglycerides to HDL-cholesterol (TG/HDL-c) indicates an atherogenic lipid profile and a risk for the development of coronary disease. Triglyceride/HDL cholesterol ratio (TG/HDL-C ratio) correlates strongly with the incidence and extent of coronary artery disease. It is a common phenomenon for both for men and women. ${ }^{15}$

It is common and generally acknowledged by the physician that, in daily practice Fenofibrates reduces TG levels to a greater extent than statins. And also, the TG level remains high after statins therapy in many patients with in the diabetes or metabolic syndrome. A combination therapy with Fenofibrates and Rosuvastatin should be more effective than statins alone in reducing TG in the mixed dyslipidemia, characterized by a lipid triad of elevated triglycerides, elevated low-density lipoproteincholesterol and reduced high-density lipoprotein cholesterol in diabetes complication condition. ${ }^{16,17}$

This study is an attempt to high light the outcomes of Rosuvastatin plus Fenofibrate in diabetic dyslipidemia. The importance of TGL/HDL ratio apart from the TCL/HDL ratio, for good lipid control in dyslipidemic patients from the a hospital record based study by following the "Third Report of the Expert Panel on detection, evaluation, and treatment of high blood cholesterol in Adults (Adult Treatment Panel III, or ATP III) presents the National Cholesterol Education Program (NCEP) updated recommendations on cholesterol testing and management". 18,19

Our record based survey fit in the new features of ATP III include, aggressive treatment of persons who are at relatively high risk for coronary heart disease due to multiple risk factors, Use of the lipoprotein profile as the first test for high cholesterol, a new level at which low HDL (high density lipoprotein) becomes a major heart disease risk factor, a new set of "Therapeutic Lifestyle Changes" to improve cholesterol levels, an increased focus on a cluster of heart disease risk factors knows as "the metabolic syndrome" and increased attention to the treatment of high triglycerides. Hence, the use of combination medications of Rosuvastatin (10mg) plus Fenofibrate $(145 \mathrm{mg})$ is often needed to effectively treat the lipid triad, by the potency of Rosuvastatin to lower LDL$\mathrm{C}$ and Fenofibrates effectiveness in lowering $\mathrm{TG}$ in treating mixed dyslipidemia.

\section{CONCLUSION}

In conclusion, after Rosuvastatin (10mg) plus Fenofibrate (145mg), therapy the lipid profile of diabetic dyslipidemia patients the atherosclerotic vascular diseases and metabolic syndrome could be improved. The combination therapies of Rosuvastatin plus Fenofibrate were safe and feasible to achieve more TG goal in terms of medical resources from our record based study.

\section{Funding: No funding sources \\ Conflict of interest: None declared}

Ethical approval: The study was approved by the Institutional Research committee of Aarupadai Veedu Medical College and Hospital, Puducherry, India (IRC No: AV/IRC/2018/079 dated 03.10.2018)

\section{REFERENCES}

1. WHO Cardiovascular diseases. Geneva; 2017. Available at: http://www.who.int/news- room/factsheets/detail/cardiovascular-diseases- (cvds). Accessed 9 November 2018. 
2. Wilson L, Bhatnagar P, Townsend N. Comparing trends in mortality from cardiovascular disease and cancer in the United Kingdom, 1983-2013: join point regression analysis. Population health metrics. 2017 Dec;15(1):23.

3. McKee PA, Castelli WP, McNamara PM, Kannel WB. The natural history of congestive heart failure: the Framingham study. New Eng J Medi. 1971 Dec 23;285(26):1441-6.

4. Krishnan MN. Coronary heart disease and risk factors in India - On the brink of an epidemic? Indian Heart J. 2012;64:364-7.

5. Luvai A, Mbagaya W, Hall AS, Barth JH. Rosuvastatin: a review of the pharmacology and clinical effectiveness in cardiovascular disease. Clinical Medicine Insights: Cardiology. 2012 Jan;6:CMC-S4324.

6. Chen YP, Chang KC, Tseng WK, Yin WH, Chen JW, Lee YT, et al. Increased rosuvastatin dose versus concomitant fenofibrate and rosuvastatin therapy to achieve lipid goal in patients with diabetes or atherosclerosis with metabolic syndrome. Acta Cardiologica Sinica. 2013 Sep;29(5):421.

7. A Randomized, Double-Blind, Placebo-Controlled with Active Comparator, 12-Week Study of DS-8500a in Subjects with Type 2 Diabetes Mellitus on Metformin. Clinical study protocol. Clinical Study Report DS8500-A-U202 Version 1.0, 30 Aug 2017 16.1.1 Protocol and Amendments. Daiichi Sankyo, Inc. 399 Thornall Street Edison, NJ 08837 United States.

8. Baer J. AACE and EAS Lipid Guidelines: - Expert Analysis. J Am Coll Cardiol. Aug 11; 2017. Available at: https: //www.acc.org/latest-incardiology/articles/2017/08/11/08/35/aace-and-easlipid-guidelines. Accessed 11 September 2018.

9. Collins P. Risk factors for cardiovascular disease and hormone therapy in women. Heart. 2006 May 1;92(suppl 3):iii24-8.

10. Pérez-López FR, Larrad-Mur L, Kallen A, Chedraui P, Taylor HS. Gender differences in cardiovascular disease: hormonal and biochemical influences. Reproductive sciences. 2010 Jun;17(6):511-31.

11. Strain JD, Farver DK. Clem JR. A review on the rationale and clinical use of concomitant rosuvastatin and fenofibrate/ fenofibric acid therapy. Clinical Pharmacology: Advances and Applications 2010;2:95-104.
12. Wankhade PS, Pedhambkar RB, Pagare RS, Pedhambkar BS. Prevalence and risk factors of dyslipidemia among male industrial workers in India. Int J Community Med Public Health. 2018;5:1458-65.

13. Iyengar S, Puri R, Narasingan S. Lipid association of India expert consensus statement on management of dyslipidemia in Indians 2016-part 1. J Prac Cardio Scien. 2016 May 1;2(2):134.

14. Wu CC, Sy R, Tanphaichitr V, Hin AT, Suyono S, Lee YT. A multicenter, double-blind study to compare the efficacy and safety of once daily atorvastatin and aimvastatin in asian people with elevated LDL cholesterol. Result from ASIA study. J Formos Med Assoc. 2002;101:478-87.

15. Sponder M, Fritzer-Szekeres M, Marculescu R, Litschauer B, Strametz-Juranek J. A new coronary artery disease grading system correlates with numerous routine parameters that were associated with atherosclerosis: a grading system for coronary artery disease severity. Vasc Health Risk Manag. 2014;10:641-7.

16. Grundy SM, Cleeman JI, Merz CN, Brewer HB, Clark LT, Hunninghake DB, et al. Coordinating Committee of the National Cholesterol Education Program. Implications of recent clinical Trials for the National Cholesterol Education Program Adult Treatment Panel III Guidelines. Circulation. 2004;110:227-39.

17. Dixit R, Jagan S. Comparative Study of Atorvastatin and Rosuvastatin in Combination with Fenofibrate in mixed Hyperlipidemia. Int $\mathbf{J}$ Pharmacol Clin Scien. Mar 2016;5:25-31.

18. Third Report of the National Cholesterol Education Program (NCEP) Expert Panel on Detection, Evaluation and Treatment of High Blood Cholesterol in Adults (Adult Treatment Panel III) final report. Circulation. 2002;106:3143-421.

19. NCEP Executive summary of the third report of the National Cholesterol Education Program (NCEP) expert panel on detection, evaluation, and treatment of high blood cholesterol in adults (adult treatment panel III). JAMA. 2001;16:2486-97.

Cite this article as: Madhana Gopal K, Meganathan M, Vithiavathi S, Prabhu Shankar S, Balamurugan K, Deepa Kameswari P. Rosuvastatin plus fenofibrate in diabetic dyslipidemia: a hospital record based study. Int J Basic Clin Pharmacol 2018;7:2297-301. 